\title{
Erythropoietin therapy and the Cardiovascular Outcome In Cardio-Renal Syndrome patients
}

Mohamed Mashahit And Khalid EI Khashab

Internal medicine and cardiology departments . Faculty of medicine , Fayoum university

\section{OBJECTIVES}

\section{METHODS}

Aim of the work was to investigate the value of erythropoietin therapy in the treatment of CRS patients with anemia and anemic heart failure and to evaluate the relationship between clinical, echocardiography and serum BNP levels in those patients compared to the standard therapy as iron supplement and blood transfusion.
The prospective study included 30 chronic renal failure patients under dialysis who are presented with anemic heart failure diagnosed according to New York Heart Association (NYHA) classification which was proved by echocardiographic finding (EFFS). Plasma BNP was measured at the beginning and at the end of the study after three months on erythropoietin therapy . patients were divided into (group 1) was treated with erythropoietin 4000 unites twice weekly and (group 2) was receiving standard treatment in the form of blood transfusion and iron (group 2).

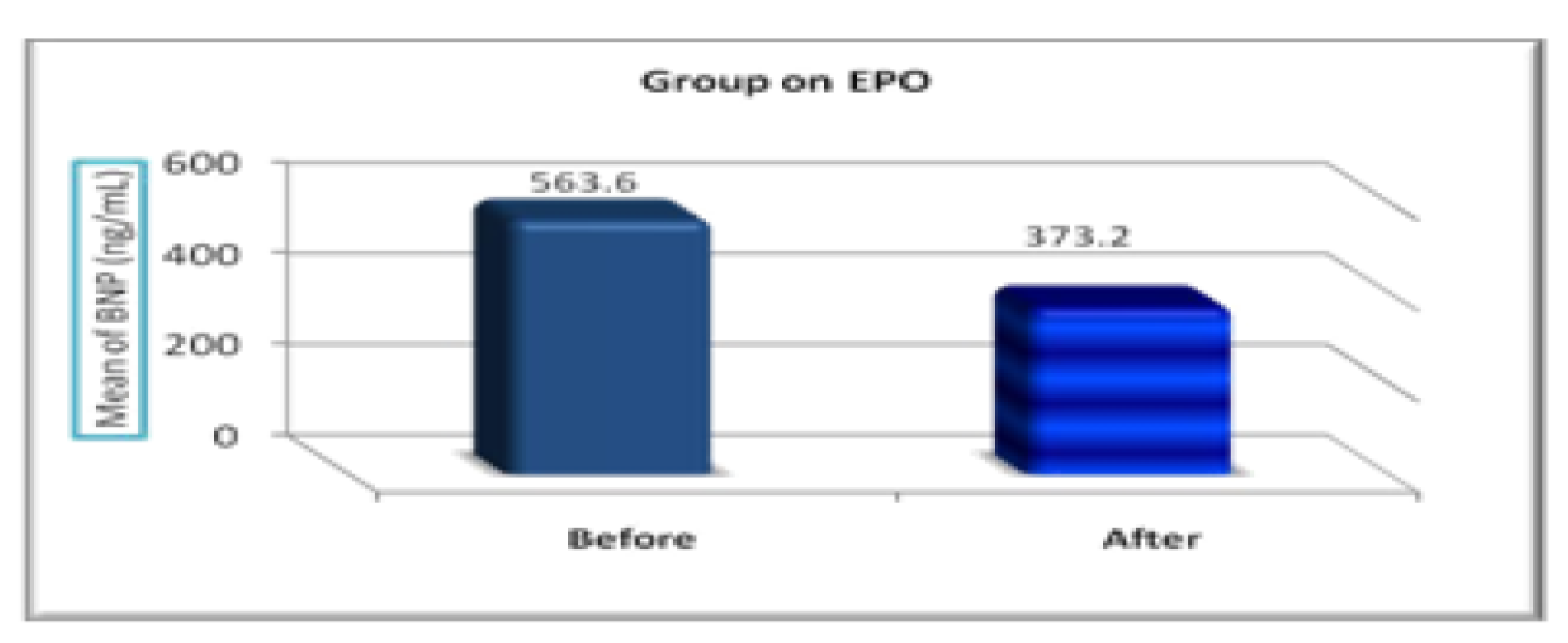

Figure (1): Mean of BNP before and after 3 months of intervention with erythropoietin for treatment of anemia
Comparison between groups of the study regarding different variables after treatment of both groups:

\begin{tabular}{|c|c|c|c|c|}
\hline Friables & $\begin{array}{c}\text { Group I } \\
\text { Mean } \pm \text { SD }\end{array}$ & $\begin{array}{c}\text { Group II } \\
\text { Mean } \pm \text { SD }\end{array}$ & $\begin{array}{l}\text { 9o changes \& } P- \\
\text { value }\end{array}$ & Sig. \\
\hline Hb & $8.864 \pm 1.4959$ & $8.420 \pm 1.1767$ & $\begin{array}{c}-\mathbf{5 \%} \% \\
0.380\end{array}$ & NS \\
\hline UREA & $101.09 \pm 19.916$ & $96.53 \pm 28.271$ & $\begin{array}{l}-4.5 \% \\
0.622\end{array}$ & NS \\
\hline Creatinine & $9.500 \pm 2.109$ & $7.460 \pm 1.469$ & $\begin{array}{l}-21.5 \% \\
0.005\end{array}$ & $\mathrm{~S}^{*}$ \\
\hline BNP & $373.214 \pm 192.013$ & $406.600 \pm 142.893$ & $\begin{array}{l}8.9 \% \\
0.432\end{array}$ & NS \\
\hline $\mathrm{EF} \%$ & $59.86 \pm 6.758$ & $59.53 \pm 7.492$ & $\begin{array}{l}-0.59 \% \\
0.904\end{array}$ & NS \\
\hline FS $\%$ & $34.06 \pm 4.017$ & $33.60 \pm 3.602$ & $\begin{array}{l}-13 \% \\
0.745\end{array}$ & NS \\
\hline LVED & $5.586 \pm .533$ & $5.293 \pm 0.884$ & $\begin{array}{l}-5.2 \% \\
0.295\end{array}$ & NS \\
\hline
\end{tabular}

\section{RESULTS}

It was found that in group -1, Six cases improved after erythropoietin therapy and so changed from class 3 to class 2. Two cases also improved after erythropoietin therapy and so changed from class 2 to class 1 . Finally , we can say that 8 cases improved and moved to a better NYHA class and this represents $53.3 \%$ improved cases of EPO cases of the study and represent $26.6 \%$ of total cases. Group - 2 on traditional therapy like blood transfusion ,iron got no remarkable improve in myocardial functions detected by non significant decreased BNP level by $17.5 \%$ but worse echo changes detected by significant decreased EF\% by $9.7 \%$, non significant decreased FS by $3.2 \%$ and significant increased LVES by $9,4 \%$.concerning $\mathrm{Hb}$ non significant increased level by $1.2 \%$ Also two cases deteriorated after traditional treatment and so one case changed from class 3 to $c$ a 4 and the other ca e changed from $c$ a 2 to $c$ a 3 while the remaining 13 ca e didn't change. Finally we can say that, no cases improved and transmitted to better NYHA class after traditional treatment and that represent $0 \%$ of total cases while there were 2 cases deterioration that represent $13 \%$ of this group and $6.5 \%$ of total cases in the study

\section{CONCLUSIONS}

In this study EPO treatment reduced BNP levels in patients with cardio-renal anemia syndrome. The correction of anemia by EPO treatment appears to be able to improve clinical outcome in this subset of patients with heart failure, detected by significantly decreased BNP level by $33.8 \%$ in comparison to non significant decreased BNP level by $17.5 \%$ but worse echo changes detected by significant decreased EF\% by $9.7 \%$, in population exposed to standard therapy

\section{Referencies}

Ronco C., Haapio M., House AA., Anavekar N. and Bellomo R.(2008):Cardiorenal syndrome. J Am Coll Cardiol 52:1527-1529.

Braam B, van der Putten K, Jie KE. and Gaillard CA. (2008): Mechanisms of disease: erythropoietin resistance in patients with both heart and kidney failure. Nat Clin Pract Nephrol.;4:47-57.

Johnson DW., Forman C. and Vesey DA . (2006) :Novel renoprotective actions of erythropoietin:New uses for an old hormone. Nephrology (Carlton) 11: 306-312. Fisher JW.(2003): Erythropoietin: physiology and pharmacology update. Exp Biol Med (Maywood); 228: 1-14. 